\title{
Phenotypic Detection and Quality Assessment of Indoor Air-Borne Microorganisms Using Passive Air Sampling Technique (Settle Plate) at A Tertiary Care Teaching Hospital in Puducherry
}

\author{
Valentina Y.* and Umadevi S. \\ Department of Microbiology, Mahatma Gandhi Medical College \& Research Institute, Pondicherry -607 403, \\ India.
}

\begin{abstract}
Microbiological quality of an indoor air is one of the indicators of proper hygienic conditions in a health care hospital. This study intends to assess the bacteriological profile of an indoor air by settle plate method. About $\mathbf{1 0 0}$ air samples were collected from various locations in the hospital by using $\mathbf{5 \%}$ Sheep blood agar and Sabouraud dextrose agarculture plates. Frequent isolation of common aerobic bacterial flora like Staphylococcus aureus (27.72\%) followed by Diptheroids (24.75\%), Bacillus spp. (24.09\%), Micrococcus (23.43\%) were observed. Among fungal isolates Aspergillus niger (25.00\%) were more prevalent followed by Zygomyces (23.07\%), Fusarium spp. (21.15\%), Aspergillus flavus (17.30\%) and Aspergillus fumigatus (13.46\%) in the hospital environment. Most of the isolates identified were a part of the normal aerobic microbial flora; however, a minimum degree of bacterial and fungal load were observed in the casualty and in the wards due to the constant patient traffic and unrestricted access to patients.

Keywords: Indoor air; Settle plate; Infection control; Nosocomial infections.
\end{abstract}

\footnotetext{
*Correspondence: tina.14.dr@gmail.com; +919655741641

(Received: 06 February 2019; accepted: 26 February 2019)
}

Citation: Valentina Y. and Umadevi S., Phenotypic Detection and Quality Assessment of Indoor Air-Borne Microorganisms Using Passive Air Sampling Technique (Settle Plate) at A Tertiary Care Teaching Hospital in Puducherry, J Pure Appl Microbiol., 2019; 13(1):241-245 doi: 10.22207/JPAM.13.1.25

(C) The Author(s) 2019. Open Access. This article is distributed under the terms of the Creative Commons Attribution 4.0 International License which permits unrestricted use, sharing, distribution, and reproduction in any medium, provided you give appropriate credit to the original author(s) and the source, provide a link to the Creative Commons license, and indicate if changes were made. 


\section{INTRODUCTION}

Quality of Indoor air plays a major role in the quality of health care facilities in hospitals. Many hospitals from various countries had reported that the important risk factors of nosocomial infections is the microbial contamination of indoor air in their hospital environment. There is an increase in contamination by both bacteria as well as fungus due to indoor humidity and the varied temperature. There are two types of air sampling, passive and active air sampling techniques ${ }^{1-5}$. In earlier days, Louis Pasteur showed significance of air borne microbes and the infections ${ }^{4}$. Many methods have been developed for isolation of bacterial and fungal in air. The microbes are collected from air through porous solid filters or aero scope ${ }^{3}$, Settle plate method ${ }^{4,6-10}$, Bio Sampler (Gelatin filters) ${ }^{11}$ and centrifugal air sampler to assess the quality of air in the hospitals ${ }^{12}$. These methods shows highly sensitive than the conventional one. However, settle plate is cheaper, cost-effective, and easier, allow the bacteria or fungus to sediment within a short-term duration ${ }^{8}$.

Most of the hospital infections (90\%) are bacterial related infections ${ }^{14-16}$. The hospital environment are contaminated with bacteria from various sources like overcrowding of visitors to the emergency, Intensive care units and wards during the visitor's time ${ }^{17}$. Usually, a nosocomial infection disseminates through air from outdoor to Indoor and this could be prevented by an immediate action of infection control ${ }^{18}$. The microbiological indoor air quality is an indicator for identification of proper sanitary conditions in the hospital, including restricted aeration ${ }^{11,13}$. Primarily an overall contamination can occurs in the hospital environment, due to the poor quality of Indoor air in the OTs, ICUs and wards. Other possibilities of nosocomial infections like improper operative techniques of surgeons, sensitivity of the patients and incorporation of surgical implants and antibiotics prophylaxis ${ }^{19}$. The principle objective of this study is to estimate and assess the prevalence rate of various microorganisms present in the indoor air by passive air sampling technique at various locations in the hospital.

\section{MATERIALS AND METHODS}

This study was carried after obtaining approval from their respective Heads' of various clinical departments like General Medicine, General Surgery, Obstetrics and Gynecology and Orthopedics of 1200 bedded tertiary care hospital, Puducherry during the period of three months(August - October 2017).

\section{Sample Collection}

A total of 100Air samplings were done (in duplicates) by using conventional passive air sampling technique - Settle plate method or Sedimentation method. These samples were obtained from various places of the hospital viz., Casualty, General Medical and Surgical wards (Male/Female), Intensive Care Units (Medical, Neonatal and Pediatrics), Obstetrics and Gynecology (Labor ward), Ortho Ward (Male/ Female) and various Operation theatres. Air Samplings were done on the third working day of every week for three months.

\section{Passive Air sampling method (Settle Plate method)}

Culture plates of $5 \%$ Sheep blood agar (SBA) for bacterial isolation and Sabouraud Dextrose Agar (SDA) for fungal isolation were used. These plates were kept exposed in the air, at their respective locations in the hospital wards, Operation theatres, casualty and ICUs for $1 \mathrm{hr}$, at $1 \mathrm{~m}$ above the floor and $1 \mathrm{~m}$ from the wall ${ }^{[11]}$. The procedure was done twice, at $8.00 \mathrm{AM}$ before the routine work started and then at 5:00 PM, after the routine active working hours ${ }^{4}$. The edges of the plates covered with paraffin film to prevent the contamination. For bacterial isolation, SBA was incubated at $37^{\circ} \mathrm{C}$ for 24 hours and for fungal SDA was incubated at $25^{\circ} \mathrm{C}$ for up to 10 days. The entire process was repeated every week at an interval of seven days for three months at the same locations. Bacteria were identified by using colony morphology, preliminary tests (Gram stain, Catalase, Oxidase and Motility test) and biochemical tests like Indole production, Methyl Red, Voges-Proskauer, Citrate utilization, Urease test and Triple sugar iron agar (TSI) test). In case of filamentous fungal colonies, Lacto Phenol Cotton Blue (LPCB) mounts were performed.

\section{RESULTS}

Tabel 1 shows the details on the percentages of micro-organisms isolated from air samples collected from various locations of the hospital. Nearly, 120 bacterial and 18 fungal 
Table 1. Percentage bacterial and fungal positivity on different locations in the hospital

\begin{tabular}{|c|c|c|c|c|c|c|c|c|c|}
\hline \multirow[t]{2}{*}{ Location } & \multicolumn{4}{|c|}{ Bacterial Isolates $(n=303)$} & \multicolumn{5}{|c|}{ Fungal Isolates $(n=52)$} \\
\hline & $\begin{array}{c}\text { Micro- } \\
\text { coccus } \\
(\%)\end{array}$ & $\begin{array}{c}\text { S. aureus } \\
(\%)\end{array}$ & $\begin{array}{c}\text { Diphth- } \\
\text { eroids } \\
(\%)\end{array}$ & $\begin{array}{c}\text { Bacillus } \\
\text { spp. } \\
(\%)\end{array}$ & $\begin{array}{l}\text { A. niger } \\
(\%)\end{array}$ & $\begin{array}{c}\text { A. flavus } \\
\text { (\%) }\end{array}$ & $\begin{array}{c}\text { A. fumigates } \\
(\%)\end{array}$ & $\begin{array}{c}\text { Fusarium } \\
\text { (\%) }\end{array}$ & $\begin{array}{c}\text { Zygomyces } \\
(\%)\end{array}$ \\
\hline Casualty & $\begin{array}{c}23 \\
(28.40)\end{array}$ & $\begin{array}{c}22 \\
(26.19)\end{array}$ & $\begin{array}{c}24 \\
(32.00)\end{array}$ & $\begin{array}{c}22 \\
(30.13)\end{array}$ & $\begin{array}{c}4 \\
(30.77)\end{array}$ & $\begin{array}{c}2 \\
(22.22)\end{array}$ & $\begin{array}{c}5 \\
(71.42)\end{array}$ & $\begin{array}{c}5 \\
(45.45)\end{array}$ & $\begin{array}{c}4 \\
(33.33)\end{array}$ \\
\hline Wards & $\begin{array}{c}29 \\
(35.80)\end{array}$ & $\begin{array}{c}31 \\
(36.90)\end{array}$ & $\begin{array}{c}29 \\
(38.67)\end{array}$ & $\begin{array}{c}22 \\
(30.13)\end{array}$ & $\begin{array}{c}5 \\
(38.46)\end{array}$ & $\begin{array}{c}2 \\
(22.22)\end{array}$ & $\begin{array}{c}1 \\
(14.28)\end{array}$ & $\begin{array}{c}1 \\
(9.10)\end{array}$ & $\begin{array}{c}2 \\
(16.67)\end{array}$ \\
\hline $\begin{array}{l}\text { Labor } \\
\text { room }\end{array}$ & $\begin{array}{c}16 \\
(19.75)\end{array}$ & $\begin{array}{c}17 \\
(20.24)\end{array}$ & $\begin{array}{c}14 \\
(18.67)\end{array}$ & $\begin{array}{c}24 \\
(32.88)\end{array}$ & $\begin{array}{c}3 \\
(23.07)\end{array}$ & $\begin{array}{c}3 \\
(33.33)\end{array}$ & $\begin{array}{c}1 \\
(14.28)\end{array}$ & $\begin{array}{c}4 \\
(36.37)\end{array}$ & $\begin{array}{c}2 \\
(16.67)\end{array}$ \\
\hline $\mathrm{ICU}$ & $\begin{array}{c}11 \\
(13.58)\end{array}$ & $\begin{array}{c}11 \\
(13.09)\end{array}$ & $\begin{array}{c}6 \\
(8.00)\end{array}$ & $\begin{array}{c}4 \\
(5.48)\end{array}$ & $\begin{array}{c}1 \\
(7.70)\end{array}$ & $\begin{array}{c}1 \\
(11.12)\end{array}$ & 0 & $\begin{array}{c}1 \\
(9.10)\end{array}$ & $\begin{array}{c}4 \\
(33.33)\end{array}$ \\
\hline OT & $\begin{array}{c}2 \\
(2.47)\end{array}$ & $\begin{array}{c}3 \\
(3.58)\end{array}$ & $\begin{array}{c}2 \\
(2.67)\end{array}$ & $\begin{array}{c}1 \\
(1.37)\end{array}$ & $\begin{array}{c}0 \\
(11.11)\end{array}$ & 1 & 0 & 0 & 0 \\
\hline Total & $\begin{array}{c}71 \\
(23.43)\end{array}$ & $\begin{array}{c}84 \\
(27.72)\end{array}$ & $\begin{array}{c}75 \\
(24.75)\end{array}$ & $\begin{array}{c}73 \\
(24.09)\end{array}$ & $\begin{array}{c}13 \\
(25.00)\end{array}$ & $\begin{array}{c}9 \\
(17.30)\end{array}$ & $\begin{array}{c}7 \\
(13.46)\end{array}$ & $\begin{array}{c}11 \\
(21.15)\end{array}$ & $\begin{array}{c}12 \\
(23.07)\end{array}$ \\
\hline
\end{tabular}

isolates were identified during 8 am and 192 bacterial and 31 fungal isolates were identified at $5 \mathrm{pm}$ sampling. In this study, the microbial contamination was found higher in wards (122 isolates) and low in operation theatres (8 isolates) which is shown in Table 2 . Different microbial flora were found contaminating indoor air, which range from higher prevalence of Staphylococcus aureus ( $27.72 \%$ ) followed by Diptheroids (24.75\%),
Bacillus spp. (24.09\%) and Micrococcus (23.43\%). Among fungal isolates, Aspergillus niger (25.00\%) was more prevalent followed by Zygomyces (23.07\%), Fusariumspp. (21.15\%), Aspergillus flavus (17.30\%) and Aspergillus fumigatus (13.46\%)in the hospital environment. There was no significant statistical difference between the pre-work and post work of microbial load of air in different locations of the hospital.

Table 2. Airborne microbial contamination from different places of the hospital

\begin{tabular}{lccccccc}
\hline Locality & \multicolumn{2}{c}{8 am } & Total & \multicolumn{2}{c}{$5 \mathrm{pm}$} & Total & P value* \\
\cline { 2 - 6 } & $\begin{array}{c}\text { Bacterial } \\
\text { load }\end{array}$ & $\begin{array}{c}\text { Fungal } \\
\text { load }\end{array}$ & & $\begin{array}{c}\text { Bacterial } \\
\text { load }\end{array}$ & $\begin{array}{c}\text { Fungal } \\
\text { load }\end{array}$ & \\
\hline Casualty & 32 & 9 & 41 & 59 & 11 & 70 & 0.5691 \\
Wards & 44 & 4 & 48 & 67 & 7 & 74 & 1.0000 \\
Labor & 29 & 4 & 33 & 42 & 9 & 51 & 0.5536 \\
room & 13 & 1 & 14 & 19 & 3 & 22 & 1.0000 \\
ICUs & 2 & 0 & 2 & 5 & 1 & 6 & 1.0000 \\
OTs & & & & & & & \\
\hline
\end{tabular}

${ }^{*} \mathrm{P}<0.05$ is considered as statistically significant

\section{DISCUSSION}

Different studies from various countries assessed the quality of indoor air in various locations like open-space offices, shopping centers, residence and industries and estimated that the air borne microorganisms were ranging from 50 to $500 \mathrm{CFU} / \mathrm{m}^{3} 1,20$. The most frequently isolated bacteria and fungus from the hospital as well as from outdoor sources are $S$. aureus, Klebsiella spp, E. coli, Pseudomonas, A. baumannii, Penicillium and Aspergillus spp. ${ }^{3}$. Table 1 shows the percentage positivity of bacterial and fungal isolates of air samples from various locations in this hospital. In this study, S. aureus $(27.72 \%)$ was 
more prevalent in the different regions of this hospital compared to the other bacterial isolates. Recently, one of the study found that an anaerobic bacterium, Clostridium difficile, were disseminated through aerosols and it was identified by slit sampling technique ${ }^{21}$. Nearly $4-11 \%$ of total microorganisms were isolated in urban air ${ }^{13}$. Two organisms were identified with human related bacteria viz., Allocococcus otitis in government hospital and Bacillus licheniformis in private health care centers by using Impact samples ${ }^{22}$. Using conventional method like settle plate technique, $57 \%$ for S. aureus and 7\% for Aspergillus niger were detected ${ }^{23}$. Similarly, in the present study, $27.72 \%$ for S. aureus and $25.00 \%$ Aspergillus niger was found higher, when compared to the other bacterial as well as fungal isolates from the hospital regions. There was no statistical significance found on microbial load between the pre-work and post work from different locations of the hospital. The major impact on microbiological indoor air quality is to prevent the risk and critical to the patients as well as healthy concern ${ }^{1}$. According to Huanget al., surface samples are highly contaminated when compared to the air samples. Nearly, $19.3 \%$ P. aeruginosa was found in the surface area and but higher percentage was found $39.1 \%$ in air samples ${ }^{3}$. However, Pseudomonas isolate is completely absent in the present study. Both surface air system and settle plate methods for air sampling procedures particularly in the operation theaters and found total viable count at rest was $12.4 \mathrm{CFU} / \mathrm{m}^{3}$ and during surgical time the count was higher $722.5 \mathrm{CFU} / \mathrm{m}^{2} / \mathrm{hr}^{4}$. Hence, we collected the samples at theatres and yielded a low prevalence of microbial contamination this may be due to absence of surgical procedures in the theaters. Schulsteret al highly recom-mended CDC guidelines for environmental infection control in health-care facilities ${ }^{18}$. Postoperative wound infections occur due to the lack of guidelines, improper sanitation and use of surgical aprons. This could be one of the reasons for spreading of nosocomial infections and emerging antibiotic resistance to the patients ${ }^{14-16}$. Fitting of laminarair flow systems with High-Efficiency Particulate Air (HEPA) Filters in operation theatres, could help to reduce the infections for the patients ${ }^{16}$. In OT samples, found highest prevalence is CONS
(53.5\%), S. aureus (33.1\%) and MRSA (7.7\%) ${ }^{6}$. In contrast to our study, S. aureus about $27.72 \%$ had obtained in various locations of our hospital. Cleaning the OTs and other wards regularly, this can reduce the microbial burden of the patients ${ }^{6}$. In some studies, the authors down regulated the settle plate method for trapping the air-borne microorganisms in comparison with nitrocellulose membrane ${ }^{24}$. Lacunae of this method are the exposure time, because of dryness and wrinkles in the agar surface. Nearly, $29.7 \%$ grampositive cocci and $70.3 \%$ gram-negative bacilli were identified from the ICUs ${ }^{19}$. In the present study, $51.15 \%, 24.75 \%$ and $24.09 \%$ of grampositive cocci, gram-negative bacilli and grampositive bacilli were isolated respectively. Highest microbial air contamination were identified in the wards (34.36\%) and the lowest contamination in operation theatres (2.25\%).

\section{CONCLUSION}

We concluded that our short-term study is highly limited only to the hospital environment and the bacteria and fungus that we isolated in various locations of the hospital were identified up to the genus level. However, we could not be able to perform antibiotic sensitivity testing as well as molecular identification for these isolates to predict the resistance and sensitive genes. Based on this study we highly recommend, to restrict the entry of visitors to ICU patients and wards during visitors time and also to avoid overcrowding. Performance of molecular diag-nosis for bacterial and fungal isolates to know the true picture of hospital acquired infections of this study. The main stay of this study is to make awareness to the physicians or surgeons and other health care committees in the hospital that intend to prevent the spreading of nosocomial infections among the patients as well as health care workers.

\section{ACKNOWLEDGEMENT}

Author is grateful to the Chairman, ViceChancellor, Dean-Academic and Dean - Research of Mahatma Gandhi Medical College and Research Institute, Puducherry (Sri Balaji Vidyapeeth, Deemed-to-be-University) for providing facilities for this Research Project. 


\section{CONFLICT OF INTEREST}

The author declares that there are no conflict of interest.

\section{REFERENCES}

1. Sampu S, Bonetta S, Bonetta S, Mosso S, Carraro E. Development of an investigation method for evaluation of microbiological indoor air quality. Proceedings: Indoor Air, 2002:752-57.

2. Brossard-Desjonqueres $Q$. Validation of a new air sampler for rapid environmental monitoring. PDA Journal of GMP and Validation in Japan, 2010;12(1): 8-12.

3. Huang PY,Shi ZY, Chen CH, Den W, Huang HM, Tsai JJ. Airborne and Surface-Bound Microbial Contamination in Two Intensive Care Units of a Medical Center in Central Taiwan. Aerosol and Air Quality Research, 2013;13:1060-69.

4. Napoli C, Marcotrigiano V, Montagna MT. Air sampling procedures to evaluate microbial contamination: a comparison between active and passive methods in operating theatres. BMC Public Health. 2012;12:594.

5. Perdelli F, Sartini M, Orlando M, Secchi V, Cristina ML. Relationship between settling microbial load and suspended microbial load in operating rooms. Ann., 2000; 12: 373-380.

6. Gebremariam TT, Desta KG, Zelelow YB, Muthupandian S. Microbial load of operating theatre at Ayder Referral Hospital, Northern Ethiopia. Afr. J. Microbiol. Res., 2015;9:639-42.

7. Whyte W. In support of settle plates. PDA J Pharm Scien Technol., 1996;50:201-4.

8. Sandle T. Settle plate exposure under unidirectional airflow and the effect of weight loss upon microbial growth. European J Parenteral \& Pharm Sciences, 2015; 20:45-50.

9. Yassin MF, Almouqatea S. Assessment of airborne bacteria and fungi in an indoor and outdoor environment. Int. J. Environ. Sci. Tech., 2010; 7:535-44.

10. Samson A, Sage A, Jones D. Use of contact plates to perform environmental settle plate testing. European J Parenteral \& Pharm Sciences, 2017;22:13-9.

11. Sudharsanam $S$, Swaminathan $S$, Ramalingam $A$, Thangavel G, Annamalai R, Steinberg R, Balakrishnan $K$, Srikanth P. Characterization of indoor bioaerosols from a a hospital ward in a tropical setting. African Health Sciences, 2012;12: 217-25.

12. Collee JG, Fraser AG, Marmion BP, Simmons A, Mackie and McCartney. Practical Medical Microbiology.
Elsevier Churchill Livingstone. New Delhi, 2006;14: 908-910.

13. Bhattacharyya S, Sarfraz A, Jaiswal N. Hospital indoor air microbial quality: Importance and monitoring. Adv. Appl. Sci. Res., 2015;6:154-6.

14. Demir F. A survey on prevention of surgical infections in operating theaters. Worldviews Evid., 2009;6: 102-113.

15. Charnley J. Postoperative infection after total hip replacement with special reference to air contamination in the operating room. Clin., 1972;87: 167-187.

16. Dharan S, Pittet D. Environmental controls in operating theatres. J. 2002;51:79-84.

17. Parker MT. Hospital-acquired infections: guidelines tolaboratory methods. World Health Organization, Regional Office for Europe, 1978.

18. Sehulster L, Chinn RY. Guidelines for environmental infection control in health-care facilities. Recommendations of CDC and the Healthcare Infection Control Practices Advisory Committee(HICPAC) MMWR Recomm Rep., 2003;52:1-42.

19. Afroz Z, Metri BC, Gilani FN, Jyothi P. Bacteriological profile of gram negative nosocomial isolates from intensive care units and their antibiogram in a tertiary care hospital of South India. Intl. J Med Microbiol and Tropical Dis., 2018;4:243-50.

20. Nunes ZG, Martins AS, Altoe ALF, Nishikawa MM, Leite MO, Aguiar PF, Fracalanzza SEL. Indoor air microbiological evaluation of offices, hospitals, industries and shopping centers. Mem Inst Oswaldo Cruz, Rio de Janeiro, 2005;100:351-7.

21. Best EL, Fawley WN, Parnell P, Wilcox MH.The potential for airborne dispersal of Clostridium difficile from symptomatic patients. Clin Infect Dis., 2010; 50:1450-7.

22. Osman ME, Ibrahim HY, Yousef FA, Elnasr AAA, Saeed Y, Hameed AAA. A study on microbiological contamination on air quality in hospitals in Egypt. Indoor and Built Environment, 2017; 0: 1-16.

23. Kasdekar MM, Duthade MM, Damle AS, Khapurkuntikar MN, Iravane JA, Bhakre JB, Gaikwad AA. Air quality monitoring of operation theatres in government medical college and hospital, Aurangabad, India. Int. J. Curr. Microbiol. App. Sci., 2016;5:42-9.

24. Napoli C, Tafuri S, Montenegro L, Cassano M, Notarnicola A, Lattarulo S, Montagna MT, Moretti B. Air sampling methods to evaluate microbial contamination in operating theatres: results of a comparative study in an orthopedics department. J Hosp Infect., 2012;80:128-132. 